\title{
Reducing Runoff Loss of Applied Nutrients in Oil Palm Cultivation Using Controlled-Release Fertilizers
}

\author{
A. Bah, ${ }^{1}$ M. H. A. Husni, ${ }^{1}$ C. B. S. Teh, ${ }^{1}$ M. Y. Rafii, ${ }^{2}$ S. R. Syed Omar, ${ }^{3}$ and O. H. Ahmed ${ }^{4}$ \\ ${ }^{1}$ Department of Land Management, Faculty of Agriculture, Universiti Putra Malaysia, 43400 Serdang, Selangor, Malaysia \\ ${ }^{2}$ Institute of Tropical Agriculture, Universiti Putra Malaysia, 43400 Serdang, Selangor, Malaysia \\ ${ }^{3}$ Diversatech (M) Fertilizer Sdn. Bhd., Bandar Baru Bangi, 43650 Selangor, Malaysia \\ ${ }^{4}$ Department of Crop Science, Faculty of Agriculture and Food Sciences, Universiti Putra Malaysia, Bintulu Campus Sarawak, \\ 97008 Bintulu, Sarawak, Malaysia
}

Correspondence should be addressed to M. H. A. Husni; husni@upm.edu.my

Received 13 August 2014; Accepted 5 November 2014; Published 7 December 2014

Academic Editor: Heike Bucking

Copyright (c) $2014 \mathrm{~A}$. Bah et al. This is an open access article distributed under the Creative Commons Attribution License, which permits unrestricted use, distribution, and reproduction in any medium, provided the original work is properly cited.

Controlled-release fertilizers are expected to minimize nutrient loss from crop fields due to their potential to supply plant-available nutrients in synchrony with crop requirements. The evaluation of the efficiency of these fertilizers in tropical oil palm agroecological conditions is not yet fully explored. In this study, a one-year field trial was conducted to determine the impact of fertilization with water soluble conventional mixture and controlled-release fertilizers on runoff loss of nutrients from an immature oil palm field. Soil and nutrient loss were monitored for one year in 2012/2013 under erosion plots of $16 \mathrm{~m}^{2}$ on $10 \%$ slope gradient. Mean sediments concentration in runoff amounted to about $6.41 \mathrm{tha}^{-1}$. Conventional mixture fertilizer posed the greatest risk of nutrient loss in runoff following fertilization due to elevated nitrogen (6.97\%), potassium (13.37\%), and magnesium (14.76\%) as percentage of applied nutrients. In contrast, this risk decreased with the application of controlled-release fertilizers, representing $0.75-2.44 \% \mathrm{~N}$, 3.55-5.09\% $\mathrm{K}$, and 4.35-5.43\% Mg loss. Meanwhile, nutrient loss via eroded sediments was minimal compared with loss through runoff. This research demonstrates that the addition of controlled-release fertilizers reduced the runoff risks of nutrient loss possibly due to their slow-release properties.

\section{Introduction}

Oil palm is mainly cultivated on highly weathered soils which belong to the orders Ultisols and Oxisols. These soils are predominantly acidic and low in fertility [1]. Fertilizers are crucial in oil palm production, accounting for $50-70 \%$ of field operational costs and about $25 \%$ of the total cost of production [2,3]. Mineral fertilizers, mainly conventional forms, account for more than $90 \%$ of fertilizers used by all types of farming systems in Malaysia [4]. The oil palm is a heavy feeder and requires quite large quantities of fertilizers to produce good yield [5]. Fertilizer management on undulating, hilly soils used for oil palm cultivation is very important because of the need to maintain fertility of the soil and to as well minimize soil erosion and nutrient loss. Frequent application of large amounts of chemical fertilizers coupled with high rainfall intensity tends to increase the risk of nutrient loss. The loss of nutrients through leaching and runoff reduces both crop productivity and economic gains. Furthermore, excess nutrient loading to ground or underground water bodies can impair designated uses of water $[6,7]$. There is a need to develop alternatives from the fertilizer industry to make mineral fertilization for high value crops such as oil palm more economically viable and ecologically compatible.

Approaches to improve crop nutrient use efficiency have been proposed $[8,9]$. Among the management practices to both improve fertilizer efficiency and reduce environmental pollution, the use of slow-release fertilizers (SRFs) and controlled-release fertilizers (CRFs) seems to be promising for widespread use in agriculture [10-13]. As compared to conventional fertilizers, the gradual release of nutrients from 


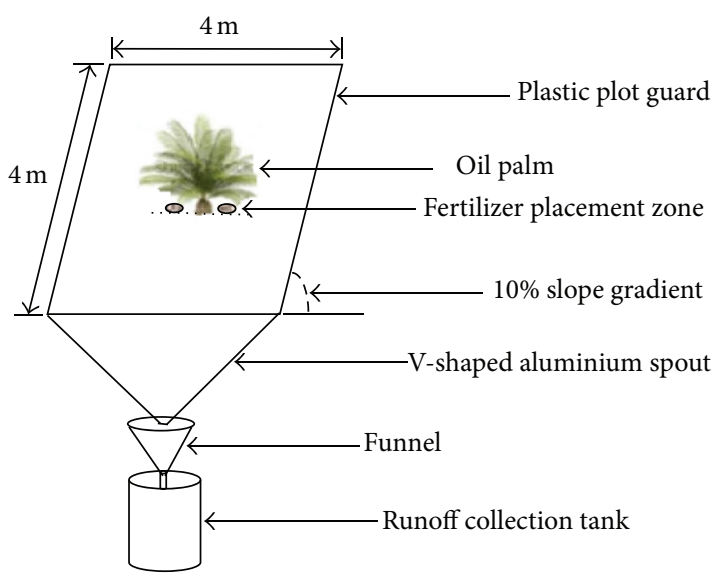

FIGURE 1: Experimental plot setup.

CRFs could be synchronized with plant needs and minimize nutrient loss through runoff and leaching to ultimately improve fertilizer use efficiency. According to the International Fertilizer Industry Association [14], controlled-release nitrogen fertilizers have agronomic advantages, especially in the tropics and in regions with light-textured soils and under heavy rainfall or irrigation, where $\mathrm{N}$ losses are particularly high.

Presently, Malaysia's oil palm industry is faced with a growing challenge of labor shortage partly due to frequent application of straight fertilizers in 4-6 splits per annum. Therefore, one of the possible approaches to address this challenge is through the adoption of improved fertilizer technologies such as the use of CRFs where fertilizer application rounds can be reduced to two splits per annum. The evaluation of efficiency of CRF is necessary to help oil palm plantations make informed decisions. The objective of this study was to evaluate whether application of controlledrelease fertilizers (AJIB CRF) instead of water soluble conventional mixture fertilizer can reduce the risk of nutrient loss via runoff and erosion.

\section{Materials and Methods}

2.1. Experimental Site Details. The study was carried out in 2012/2013 on a newly established oil palm farm at the experimental station of Universiti Putra Malaysia Agriculture Park in Puchong, Selangor $\left(02^{\circ} \mathrm{N} 59.035^{\prime}, 101^{\circ} \mathrm{E} 38.913^{\prime}\right)$. Initially, the field was a fallow grassland. The area has a humid tropical climate with a mean annual rainfall of $2700 \mathrm{~mm}$ and temperature of $25.3^{\circ} \mathrm{C}$ [15]. Experimental plots measuring $4 \mathrm{~m} \times 4 \mathrm{~m}$ and delineated along uniform land slope of $10 \%$ were demarcated with transparent plastic sheets inserted $5 \mathrm{~cm}$ deep into the soil and $15 \mathrm{~cm}$ above soil surface to prevent lateral flow and control the risk of plot contamination (Figure 1). Twelve-month-old oil palm clones (AA Hybrida IS) obtained from Applied Agricultural Resources Company were planted using the $9 \mathrm{~m} \times 9 \mathrm{~m} \times 9 \mathrm{~m}$ triangular system. Daily precipitation records were taken throughout the experimental period using rain gauge. Runoff was routed via
TABLE 1: Fertilizer application treatments.

\begin{tabular}{lcccc}
\hline \multirow{2}{*}{ Fertilizer treatments } & \multicolumn{4}{c}{ Nutrient rate $\left(\mathrm{kg} \mathrm{ha}^{-1} \mathrm{yr}^{-1}\right)$} \\
& $\mathrm{N}$ & $\mathrm{P}$ & $\mathrm{K}$ & $\mathrm{Mg}$ \\
\hline Control & 0.00 & 0.00 & 0.00 & 0.00 \\
Mixture & 48.96 & 13.07 & 81.60 & 5.86 \\
CRFB-60\% & 32.64 & 8.71 & 54.40 & 3.91 \\
CRFG-60\% & 32.64 & 8.71 & 54.40 & 3.91 \\
CRFB-100\% & 48.96 & 13.07 & 81.60 & 5.86 \\
CRFG-100\% & 48.96 & 13.07 & 81.60 & 5.86 \\
\hline
\end{tabular}

a V-shaped stainless steel aluminum spout attached to a funnel-fitted tank. The experiment was arranged in three blocks (replicates) with six treatments established perpendicular to the slope.

2.2. Experimental Soil. Soil particle size distribution measurement was based on the pipette method [16], while the bulk density of the soil was determined using core rings as outlined by Teh and Talib [17]. Soil pH, EC, and CEC were determined following standard protocols [18-20]. Total soil carbon and nitrogen were analysed using TruMac CNS Analyzer (LECO, St. Joseph), which utilises the dry combustion principle. Soil exchangeable $\mathrm{K}, \mathrm{Ca}, \mathrm{Mg}$, and CEC using $1 \mathrm{M}$ $\mathrm{NH}_{4} \mathrm{OAc}(\mathrm{pH} 7.0)$ [21, 22] and $\mathrm{P}$ using Bray II method [23] were determined.

2.3. Fertilizer Treatments. The treatments evaluated in this study were as follows:

(i) control (no fertilizer),

(ii) mixture (water soluble mixed fertilizer),

(iii) CRFB-60\% (60\% dosage of briquette CRF),

(iv) CRFG-60\% (60\% dosage of granular CRF),

(v) CRFB-100\% (full dosage of briquette CRF),

(vi) CRFG-100\% (full dosage of granular CRF).

T2 consists of a mixture of water soluble straight fertilizers, namely, ammonium sulfate $(21 \% \mathrm{~N})$, Christmas Island Rock Phosphate $\left(33 \% \mathrm{P}_{2} \mathrm{O}_{5}\right)$, Muriate of Potash $\left(60 \% \mathrm{~K}_{2} \mathrm{O}\right)$, and Kieserite $(27 \% \mathrm{MgO})$. The grade of the coated CRFs (AJIB CRF) is 10-6-20-2. Briquette CRF is spherical in shape with a size of about $5 \mathrm{~cm}$ in length, while granular CRF is pelletized and is approximately $1 \mathrm{~cm}$ in length. The full dosage of fertilizer application was based on standard recommended rates for immature oil palm. The treatments were arranged in a randomized complete block design (RCBD) with three replications (Table 1). The fertilizers were surface-placed under the plant canopy in two splits per year at six months' intervals.

2.4. Runoff Collection and Analysis. Following each rainfall event, surface runoff water plus eroded sediments per plot was collected for one year (October 2012 to September 2013) using tanks. For each rainfall event, the total water volume per each tank was recorded and $1 \mathrm{~L}$ subsamples were collected 
TABLE 2: Soil textural classification of study site $(0-20 \mathrm{~cm})$ and sediments distribution in runoff.

\begin{tabular}{|c|c|c|c|c|}
\hline \multirow{2}{*}{ Sample } & \multicolumn{3}{|c|}{ Textural distribution (\%) } & \multirow{2}{*}{ Soil texture class (USDA) } \\
\hline & Sand & Silt & Clay & \\
\hline Soil & 63 & 6 & 31 & Sandy clay loam \\
\hline Sediments & 32 & 40 & 28 & Clay loam \\
\hline
\end{tabular}

in detergent-washed polypropylene bottles, after which they were transported to the laboratory, filtered, and analyzed for $\mathrm{N}, \mathrm{P}, \mathrm{K}$, and $\mathrm{Mg}$ content. All tanks were emptied and thoroughly cleaned with distilled water after each sample collection event. The sediments retained after filtration of runoff samples with Whatman number 5 were oven-dried at $60^{\circ} \mathrm{C}$ for $24 \mathrm{~h}$ and weighed with an electronic balance. Sediment loss from each plot was calculated by multiplying the volume of runoff with the nutrients concentration in the analyte. Soil loss was converted into sediment yield in $\mathrm{tha}^{-1}$. Dried sediments and runoff filtrates were separately analyzed for their $\mathrm{N}, \mathrm{P}, \mathrm{K}$, and $\mathrm{Mg}$ contents following standard procedures as stated above.

Analysis of variance was used to detect treatment effect, whereas treatment means were compared using Duncan's new multiple range test (DNMRT) at $P \leq 0.05$ with statistical analysis system (SAS) software (Version 9.3).

\section{Results and Discussion}

3.1. Rainfall, Runoff, and Soil Loss. The texture of the soil in the study area is classified as sandy clay loam (Typic Kandiudult) having a deep kandic horizon with clay content between 18 and 35\% [24]. Based on texture and its friable nature, this soil is prone to erosion but may also be highly permeable to enhance water infiltration. Although soil consisted of $63 \%$ sand, clay $31 \%$, and $6 \%$ silt, there was substantial loss of silt (40\%) in the eroded sediments compared to sand (32\%) and clay (28\%) as shown in Table 2. The higher loss of silt particles in the eroded sediments relates to the lightness of this particle.

The annual recorded precipitation was $2635 \mathrm{~mm}$. Highest observed rainfall occurred in the months of October $(316 \mathrm{~mm})$ and November $(302 \mathrm{~mm})$ in 2012. A short dry spell was observed in February, June, and August, 2013, as a result of seasonal changes in rainfall distribution patterns in the area. Figure 2 shows monthly generated runoff and soil loss due at the experimental site. A total of $371 \mathrm{~mm}$ of runoff volume was recorded during the study period. Also, runoff volume as percentage of rainfall ranged from 5 to $20 \%$ with a mean value of $14 \%$. This result relates to the relatively high infiltration $\left(5.40 \mathrm{~mm} \mathrm{hr}^{-1}\right)$ of the soil. The annual sediment loss was $6.41 \mathrm{tha}^{-1}$ and maximum loss $\left(1.05 \mathrm{tha}^{-1}\right)$ occurred in the month of November 2012 (Figure 2).

Soil erosion studies in oil palm fields in Malaysia have shown a wide range of soil loss. According to reports by PORIM [25] and Hartemink [26] soil loss ranges from 13 to $78 \mathrm{Mgha}^{-1} \mathrm{yr}^{-1}$ for Oxisols and 1 to $28 \mathrm{Mg} \mathrm{ha}^{-1} \mathrm{yr}^{-1}$ for Ultisols. The results of the present study are comparable to

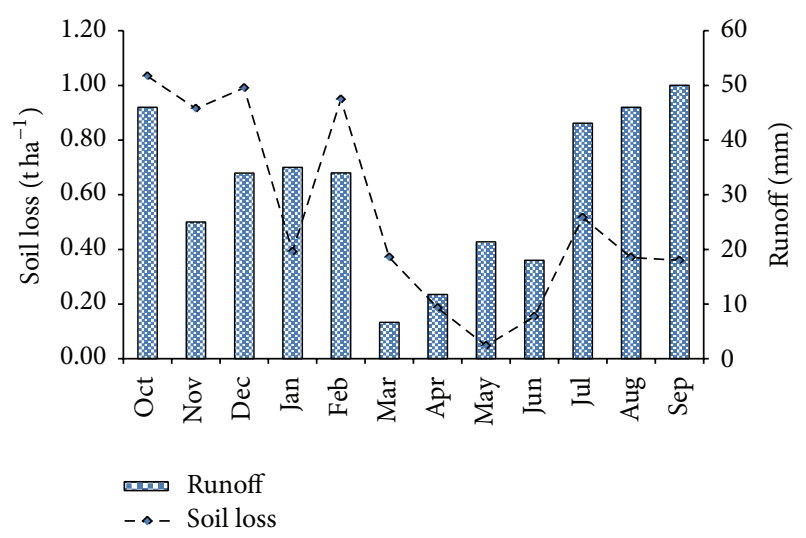

Figure 2: Monthly soil loss and runoff during study period $(2012 / 2013)$.

that of Corley and Tinker [27] who reported soil loss of less than $9 \mathrm{tha}^{-1}$. Similar findings have also been previously reported [28, 29], where soil erosion losses from oil palm fields were in the range of 7.47-14.92 $\mathrm{tha}^{-1}$. Loss of nutrients through runoff and sediments relates to soil texture, age of palms, soil topography and infiltrability, land clearing, inadequate soil conservation measures, and the lag time between fertilizer application and rainfall $[30,31]$.

3.2. Nutrient Loss in Runoff and Eroded Sediments. As shown in Table 3, net annual losses of nutrients in runoff varied significantly between soluble mixture and CRF treatments, but the differences were not significant between briquette and granular CRFs. Comparison of the overall nutrients concentration of the different treatments indicated that runoff losses of nutrients were highest in mixture fertilizer compared with the controlled-release fertilizers (AJIB CRF) and the control. The loss of nutrients from applied mixture treatments was rapid at the initial stage following first fertilization in October, after which it declined rapidly and picked up again in June following second fertilization (Figure 3). Cumulatively, the annual loss of $\mathrm{N}$ through runoff in the plots treated with mixture fertilizers accounted was $4.78 \mathrm{~kg} \mathrm{ha}^{-1}$ whereas the $\mathrm{N}$ loss from applied CRF fertilizers ranged between 1.73 and $2.56 \mathrm{~kg} \mathrm{ha}^{-1}$. The net losses of $\mathrm{K}$ and $\mathrm{Mg}$ were greatest for mixture fertilizer treatment, accounting for $13 \%$ and $15 \%$, respectively, of the added fertilizer. The average annual loss of $\mathrm{P}$ in the runoff due to fertilization was relatively low with full dosage of granular CRF accounting for the highest loss (4\%). The losses of nutrients from the reduced dosages of CRFs (CRFB-60\% and CRFG-60\%) were consistently lower than their full dosage counterparts, although the latter showed better plant response in terms of $\mathrm{N}$ and $\mathrm{Mg}$ uptake. By comparing the nutrients lost through surface runoff with those lost in the eroded sediments (Table 3), it is clear that runoff losses of nutrients in all treatments were substantially greater than those lost in displaced sediments.

Nutrient loss data in this current study are consistent with other studies conducted in Malaysia. For example, studies conducted by Maene et al. [28] showed that 11\% N, 3\% P, 5\% 
TABLE 3: Summary of net nutrient loss in oil palm ecosystem through surface runoff and eroded sediments.

\begin{tabular}{|c|c|c|c|c|}
\hline Fertilizer treatments & $\begin{array}{l}\text { Net loss in runoff } \\
\left(\mathrm{kg} \mathrm{ha}^{-1} \mathrm{yr}^{-1}\right)\end{array}$ & $\begin{array}{l}\text { Net loss in eroded sediments } \\
\qquad\left(\mathrm{kg} \mathrm{ha}^{-1} \mathrm{yr}^{-1}\right)\end{array}$ & $\begin{array}{l}\text { Net total loss } \\
\left(\mathrm{kg} \mathrm{ha}^{-1} \mathrm{yr}^{-1}\right)\end{array}$ & $\begin{array}{c}\text { Net loss as \% of nutrient } \\
\text { applied }\end{array}$ \\
\hline & \multicolumn{4}{|c|}{ Nitrogen $(\mathrm{N})$} \\
\hline Control & $1.20^{\mathrm{c}} \pm 0.04$ & $0.17^{\mathcal{C}} \pm 0.01$ & $1.37^{\mathrm{c}}$ & - \\
\hline Mixture & $3.85^{\mathrm{a}} \pm 0.22$ & $0.93^{\mathrm{a}} \pm 0.27$ & $4.78^{\mathrm{a}}$ & 6.97 \\
\hline CRFB-60\% & $1.33^{\mathrm{bc}} \pm 0.02$ & $0.40^{\mathrm{ab}} \pm 0.24$ & $1.73^{\mathrm{bc}}$ & 0.75 \\
\hline CRFG-60\% & $1.39^{b c} \pm 0.24$ & $0.39^{\mathrm{ab}} \pm 0.20$ & $1.78^{\mathrm{bc}}$ & 0.84 \\
\hline CRFB-100\% & $1.81^{\mathrm{b}} \pm 0.26$ & $0.41^{\mathrm{ab}} \pm 0.12$ & $2.22^{\mathrm{b}}$ & 1.74 \\
\hline \multirow[t]{2}{*}{ CRFG-100\% } & $1.98^{\mathrm{b}} \pm 0.30$ & $0.58^{\mathrm{ab}} \pm 0.16$ & $2.56^{\mathrm{b}}$ & 2.44 \\
\hline & \multicolumn{4}{|c|}{ Phosphorus (P) } \\
\hline Control & $0.40^{\mathrm{cb}} \pm 0.16$ & $0.12^{\mathrm{b}} \pm 0.01$ & $0.52^{\mathrm{b}}$ & - \\
\hline Mixture & $0.70^{\mathrm{ab}} \pm 0.09$ & $0.30^{\mathrm{a}} \pm 0.07$ & $1.00^{\mathrm{a}}$ & 3.74 \\
\hline CRFB-60\% & $0.45^{\mathrm{b}} \pm 0.14$ & $0.24^{\mathrm{ab}} \pm 0.05$ & $0.69^{\mathrm{ab}}$ & 1.31 \\
\hline CRFG-60\% & $0.49^{\mathrm{b}} \pm 0.01$ & $0.29^{\mathrm{a}} \pm 0.03$ & $0.78^{\mathrm{ab}}$ & 2.02 \\
\hline CRFB-100\% & $0.64^{\mathrm{ab}} \pm 0.03$ & $0.31^{\mathrm{a}} \pm 0.02$ & $0.95^{\mathrm{a}}$ & 3.28 \\
\hline \multirow[t]{2}{*}{ CRFG-100\% } & $0.92^{\mathrm{a}} \pm 0.19$ & $0.15^{\mathrm{b}} \pm 0.06$ & $1.07^{\mathrm{a}}$ & 4.22 \\
\hline & \multicolumn{4}{|c|}{ Potassium (K) } \\
\hline Control & 3. $70^{c} \pm 0.17$ & $0.45^{\mathfrak{c}} \pm 0.11$ & $3.70^{\mathrm{c}}$ & - \\
\hline Mixture & $12.48^{\mathrm{a}} \pm 0.87$ & $2.14^{\mathrm{a}} \pm 0.37$ & $14.62^{\mathrm{a}}$ & 13.37 \\
\hline CRFB- $60 \%$ & $5.56^{\mathrm{b}} \pm 0.13$ & $1.08^{\mathrm{b}} \pm 0.21$ & $6.64^{\mathrm{b}}$ & 3.60 \\
\hline CRFG-60\% & $5.35^{\mathrm{b}} \pm 0.17$ & $1.25^{\mathrm{b}} \pm 0.37$ & $6.60^{\mathrm{b}}$ & 3.55 \\
\hline CRFB-100\% & $5.96^{\mathrm{b}} \pm 0.16$ & $1.32^{\mathrm{b}} \pm 0.17$ & $7.28^{\mathrm{b}}$ & 4.38 \\
\hline \multirow[t]{2}{*}{ CRFG-100\% } & $6.83^{\mathrm{b}} \pm 0.35$ & $1.03^{\mathrm{b}} \pm 0.23$ & $7.86^{\mathrm{b}}$ & 5.09 \\
\hline & \multicolumn{4}{|c|}{ Magnesium (Mg) } \\
\hline Control & $0.51^{b} \pm 0.04$ & $0.11^{c} \pm 0.02$ & $0.62^{c}$ & - \\
\hline Mixture & $1.20^{\mathrm{a}} \pm 0.14$ & $0.28^{\mathrm{a}} \pm 0.05$ & $1.48^{\mathrm{a}}$ & 14.76 \\
\hline CRFB-60\% & $0.70^{\mathrm{ab}} \pm 0.08$ & $0.19^{\mathrm{ab}} \pm 0.04$ & $0.89^{\mathrm{b}}$ & 4.72 \\
\hline CRFG-60\% & $0.58^{\mathrm{b}} \pm 0.03$ & $0.29^{\mathrm{a}} \pm 0.10$ & $0.87^{\mathrm{b}}$ & 4.35 \\
\hline CRFB-100\% & $0.76^{\mathrm{ab}} \pm 0.07$ & $0.17^{\mathrm{ab}} \pm 0.02$ & $0.93^{\mathrm{b}}$ & 5.43 \\
\hline CRFG-100\% & $0.68^{\mathrm{ab}} \pm 0.02$ & $0.21^{\mathrm{ab}} \pm 0.09$ & $0.89^{\mathrm{b}}$ & 4.65 \\
\hline
\end{tabular}

All analyses are mean \pm standard error of mean (SEM). Means not sharing a common letter are significantly different by DNMRT $(P \leq 0.05)$.

$\mathrm{K}, 6 \% \mathrm{Mg}$, and 5\% Ca of applied fertilizers were lost through surface runoff alone during a low rainfall $(1426 \mathrm{~mm})$ on a $9 \%$ slope. The findings further indicated that the harvesting paths are the most susceptible areas to surface runoff due to compaction of the soil by machinery. Another study [32] revealed that $5-8 \% \mathrm{~N}, 10-15 \% \mathrm{~K}, 4-6 \% \mathrm{Mg}$, and $<2 \% \mathrm{P}$ were lost through runoff. This suggests that soluble nutrients such as $\mathrm{N}, \mathrm{K}$, and $\mathrm{Mg}$ are more susceptible to runoff losses. According to Wallace et al. [33], large losses of nutrients via surface runoff are still possible when a large rainfall event occurs soon after application of a fertilizer amendment.

The macronutrient release pattern varied substantially between mixture and CRF fertilizers (Figure 3). The nutrients released from mixture fertilizer (except for $\mathrm{P}$ ) were higher and varied more after fertilization. Coated fertilizers (CRFs) gradually released nutrients compared to that of the mixture fertilizer. Mixture fertilizer showed lower P release in runoff due to low solubility of its $\mathrm{P}$ content from the phosphate rock source in contrast with CRF treatments, which are formulated with diammonium phosphate (DAP) as $\mathrm{P}$ source.
An examination of the nutrient release pattern shows that, immediately after fertilizer application in October 2012 and April 2013, the mean soluble N, K, and Mg concentrations in runoff were greatest for mixture fertilizer treatment and then followed by CRF treatments (Figure 3). Mean loss of nutrients in runoff from fertilized plots decreased significantly from the months of January to May, such that losses were similar to those observed for the unfertilized treatment. This trend is more obvious for nutrients such as $\mathrm{N}, \mathrm{K}$, and $\mathrm{Mg}$ than for $\mathrm{P}$.

3.3. Effect of Rainfall Intensity. The effects of rainfall intensity on nutrient loss were explored for the months of November (2012) and April (2013) and the findings suggest that $76 \%$ of the rainfall occurred at intensities below $10 \mathrm{~mm} \mathrm{hr}^{-1}$ and $13 \%$ in excess of $20 \mathrm{~mm} \mathrm{hr}^{-1}$ (Figure 4). Research findings suggest that rainfall intensity is one of the most important factors that contribute to soil loss and runoff [34, 35]. Soil erosion due to rainfall involves series of complex processes commencing from detachment by raindrop impact, transport of entrained soil particles by rain splash or surface flow, and 


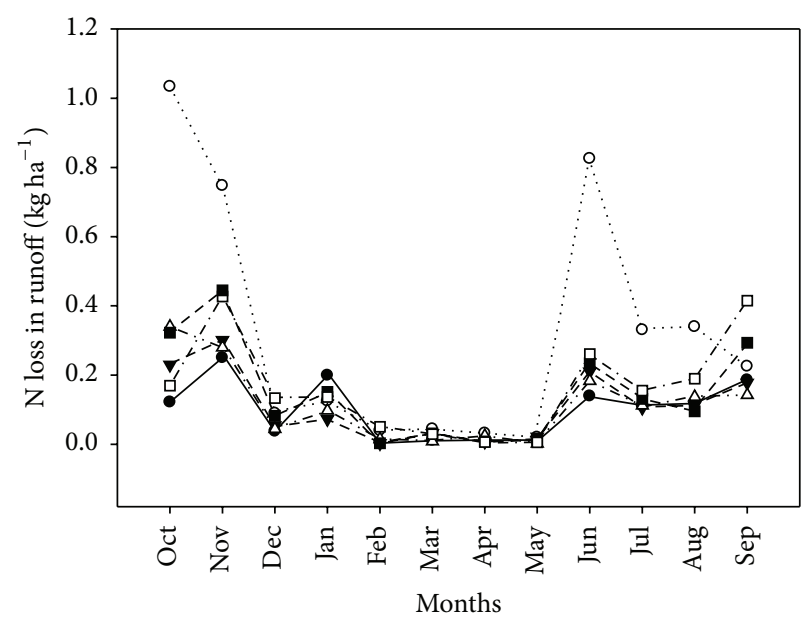

(a)

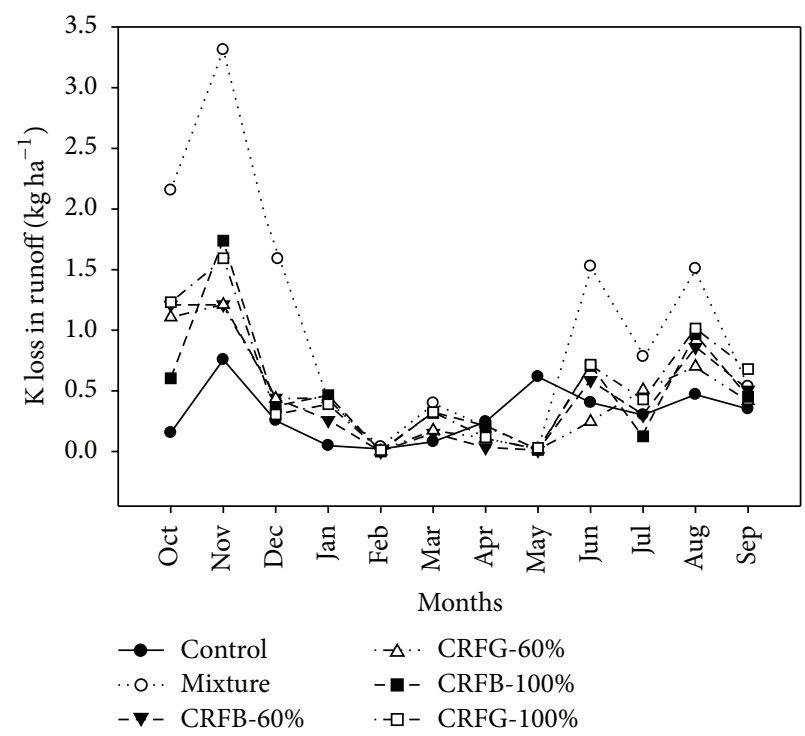

(c)

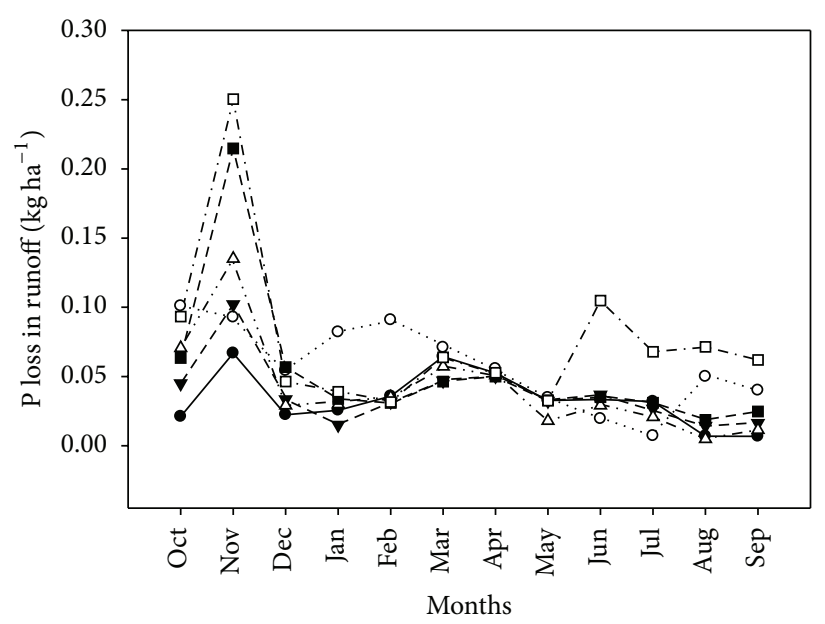

(b)

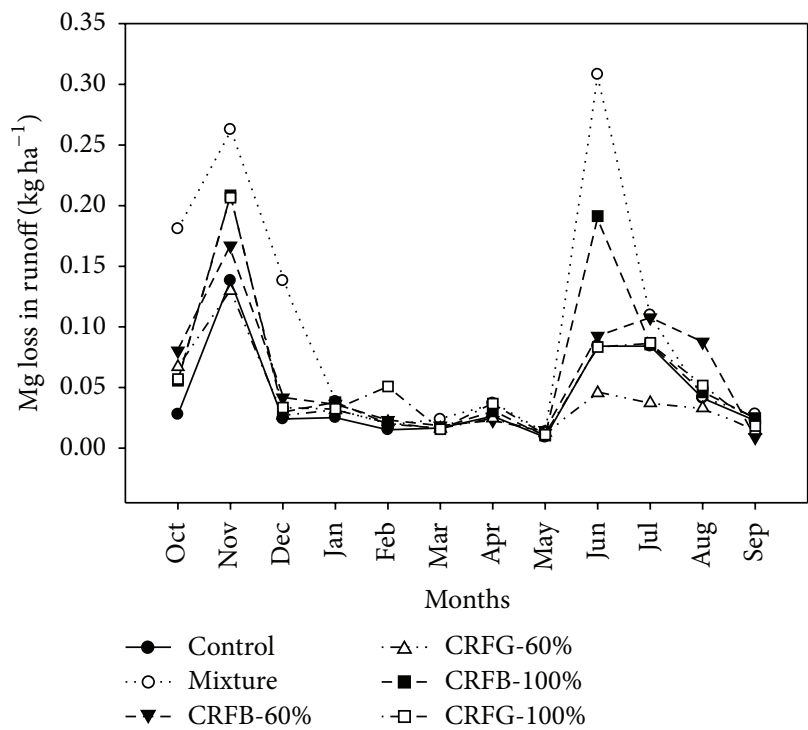

(d)

FIGURE 3: Monthly runoff loss patterns of nutrients as impacted by fertilizer application.

then deposition. There is strong relationship between rainfall, runoff, and soil erosion by water. The occurrence of runoff, whether small or huge, always results in decline of soil fertility due to loss of topsoil and nutrients, loss of organic matter, and the consequent loss of the soil's capacity to retain nutrients and water.

Nutrient runoff potential during storm events is influenced by numerous factors, including amount and intensity of rainfall, antecedent rainfall conditions, timing and rate of fertilization, ponding, and irrigation management practices [36]. Rainfall intensity is considered a key determinant factor that influences the loss of soil and nutrients. As shown in Figure 4, the loss of soil through runoff significantly increased with increase in rainfall intensity. A recent study on the interactions between rainfall intensities and soil surface interrill erosion [37] showed that the soil erosion rates spiked following sharp increase in rainfall intensity. Attempts were conducted to evaluate $\mathrm{P}$ and $\mathrm{N}$ in surface runoff in relation to rainfall intensity and hydrology for two soils along a single hill slope and the results revealed that nutrient loss was significantly greater under the high intensity rainfall due to larger runoff volumes [38].

Linear relationships were observed between the rainfall intensity and nutrient $(\mathrm{N})$ loss (Figure 5). The coefficients of determination $\left(R^{2}\right)$ of the linear regressions were high $(P<0.01)$ for all treatments, ranging from 0.778 to 0.939 , indicating the influence of rainfall intensity on nutrient loss. A study on nutrient loss of a limed soil in a reservoir area found a positive regressive relationship between nutrient loss and rainfall intensity [39]. Previously, it has also been found that the loss of $\mathrm{P}$ has a strongly positive relationship with rainfall intensity [40]. A study on the effect of rainfall intensity and soil surface cover on losses of sediment and soil organic carbon (SOC) via surface runoff found that higher 
TABLE 4: Frond number of immature oil palms at different months after fertilization (MAF).

\begin{tabular}{|c|c|c|c|c|c|}
\hline \multirow{2}{*}{ Fertilizer treatments } & \multicolumn{5}{|c|}{ Frond number plant $^{-1}$} \\
\hline & $0 \mathrm{MAF}$ & $3 \mathrm{MAF}$ & $6 \mathrm{MAF}$ & $9 \mathrm{MAF}$ & $12 \mathrm{MAF}$ \\
\hline Control & $13^{\mathrm{a}} \pm 0.12$ & $17^{\mathcal{C}} \pm 0.50$ & $20^{\mathrm{b}} \pm 0.49$ & $23^{\mathrm{c}} \pm 0.99$ & $26^{\mathrm{c}} \pm 1.53$ \\
\hline Mixture & $13^{\mathrm{a}} \pm 0.29$ & $19^{\mathrm{ab}} \pm 1.15$ & $24^{\mathrm{ab}} \pm 1.00$ & $28^{\mathrm{b}} \pm 0.55$ & $32^{\mathrm{b}} \pm 0.75$ \\
\hline CRFB- $60 \%$ & $12^{\mathrm{a}} \pm 0.27$ & $19^{\mathrm{ab}} \pm 0.27$ & $26^{\mathrm{a}} \pm 0.82$ & $29^{\mathrm{ab}} \pm 0.56$ & $33^{\mathrm{ab}} \pm 0.67$ \\
\hline CRFG-60\% & $12^{\mathrm{a}} \pm 0.27$ & $18^{\mathrm{ab}} \pm 0.81$ & $27^{\mathrm{a}} \pm 0.46$ & $31^{\mathrm{a}} \pm 0.22$ & $35^{\mathrm{a}} \pm 1.20$ \\
\hline CRFB-100\% & $12^{\mathrm{a}} \pm 0.12$ & $19^{\mathrm{ab}} \pm 0.87$ & $25^{\mathrm{ab}} \pm 1.35$ & $31^{\mathrm{a}} \pm 1.05$ & $34^{\mathrm{ab}} \pm 1.33$ \\
\hline CRFG-100\% & $13^{\mathrm{a}} \pm 0.24$ & $20^{\mathrm{a}} \pm 0.43$ & $26^{\mathrm{a}} \pm 1.98$ & $32^{\mathrm{a}} \pm 0.66$ & $36^{\mathrm{a}} \pm 0.48$ \\
\hline
\end{tabular}

All analyses are mean \pm standard error of mean (SEM). Means not sharing a common letter are significantly different by DNMRT $(P \leq 0.05)$.

TABLE 5: Effects of fertilizer treatments on leaf and rachis nutrients concentration of oil palm at 12 MAF.

\begin{tabular}{lcccc}
\hline \multirow{2}{*}{ Fertilizer treatments } & \multicolumn{4}{c}{ Leaf nutrients concentration (\%) } \\
& $\mathrm{N}$ & $\mathrm{P}$ & $\mathrm{K}$ & $\mathrm{Mg}$ \\
\hline Control & $2.03^{\mathrm{d}} \pm 0.03$ & $0.12^{\mathrm{c}} \pm 0.01$ & $1.10^{\mathrm{d}} \pm 0.01$ & $0.26^{\mathrm{c}} \pm 0.02$ \\
Mixture & $2.28^{\mathrm{bc}} \pm 0.03$ & $0.20^{\mathrm{ab}} \pm 0.02$ & $1.55^{\mathrm{bc}} \pm 0.01$ & $0.42^{\mathrm{b}} \pm 0.01$ \\
CRFB-60\% & $2.27^{\mathrm{ab}} \pm 0.13$ & $0.21^{\mathrm{ab}} \pm 0.01$ & $1.57^{\mathrm{bc}} \pm 0.04$ & $0.43^{\mathrm{b}} \pm 0.02$ \\
CRFG-60\% & $2.30^{\mathrm{bc}} \pm 0.09$ & $0.20^{\mathrm{ab}} \pm 0.01$ & $1.53^{\mathrm{c}} \pm 0.03$ & $0.44^{\mathrm{b}} \pm 0.01$ \\
CRFB-100\% & $2.38^{\mathrm{a}} \pm 0.10$ & $0.24^{\mathrm{a}} \pm 0.01$ & $1.66^{\mathrm{ab}} \pm 0.01$ & $0.56^{\mathrm{a}} \pm 0.02$ \\
CRFG-100\% & $2.46^{\mathrm{a}} \pm 0.03$ & $0.25^{\mathrm{a}} \pm 0.01$ & $1.75^{\mathrm{a}} \pm 0.04$ & $0.55^{\mathrm{a}} \pm 0.01$ \\
\hline
\end{tabular}

All analyses are mean \pm standard error of mean (SEM). Means not sharing a common letter are significantly different by DNMRT $(P \leq 0.05)$.

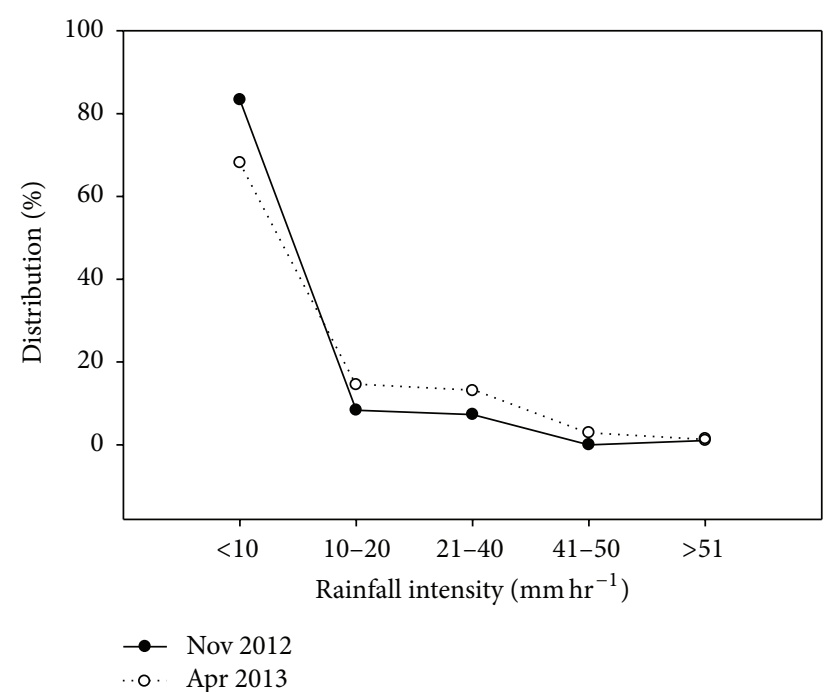

FIGURE 4: Rainfall intensity distribution for the months of November (2012) and April (2013).

rainfall intensity and lower vegetative cover produced higher sediment and consequently higher nutrient loss [41].

3.4. Oil Palm Response to Fertilizer Treatments. Oil palm response to fertilizer treatments during the first six months after fertilization (MAF) appears to show no significant variation $(P \leq 0.05)$ in terms of frond production. However, at $12 \mathrm{MAF}$, plants that received treatments of granular CRFs showed significant improvement in frond number by $64-66 \%$ compared to mixture (59\%) and control (52\%) treatments (Table 4).

The effects of fertilizer treatments on foliar nutrient content of frond ${ }^{\#} 3$ are given. In general, leaf nutrient concentrations for $\mathrm{N}, \mathrm{P}, \mathrm{K}$, and $\mathrm{Mg}$ for fertilized plants were higher at 12 MAF compared to 0, 3, 6, and 9 MAF. This is probably due to the cumulative effect of the fertilizers which were applied in two rounds per annum at six months' interval. Plant response in terms of nutrients uptake appears to be higher with application of full dose CRF treatments (Table 5). For full dose granular CRF treated plants, foliar $\mathrm{N}$ increased from $2.10 \%$ to $2.46 \%$, while foliar $\mathrm{K}$ and $\mathrm{Mg}$ increased from $1.35 \%$ to $1.75 \%$ and $0.25 \%$ to $0.55 \%$, respectively. Leaf analyses for the purpose of diagnosing nutritional status of oil palm have proven successful in most industrial plantations worldwide for several decades, due to the fact that the obtained information serves as a reliable indicator for annual guidance of mineral fertilization [42]. It has been reported that foliar concentrations of $\mathrm{N}, \mathrm{Mg}, \mathrm{B}, \mathrm{Cu}, \mathrm{Fe}$, and Mo were significantly affected by controlled-release fertilizer treatments on container-grown ponderosa pine seedlings [43].

\section{Conclusion}

Controlled-release fertilizers (AJIB CRF) application in an immature oil palm field potentially decreased surface runoff loss of nutrients. This could be attributed to the fact that nutrient elements in CRFs are readily and slowly available for plant uptake over a given period. It is imperative to note that fertilizers should be applied during periods of less rainfall events in order to limit nutrient and soil loss due to the effect of high rainfall intensity. Considering the long term economic 


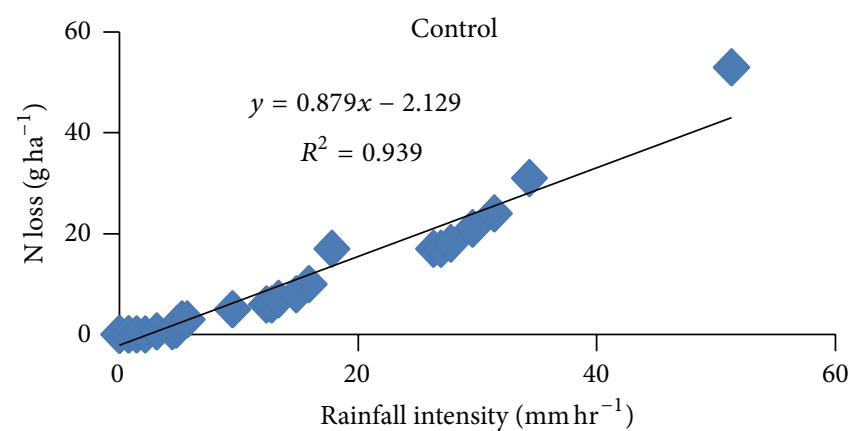

(a)

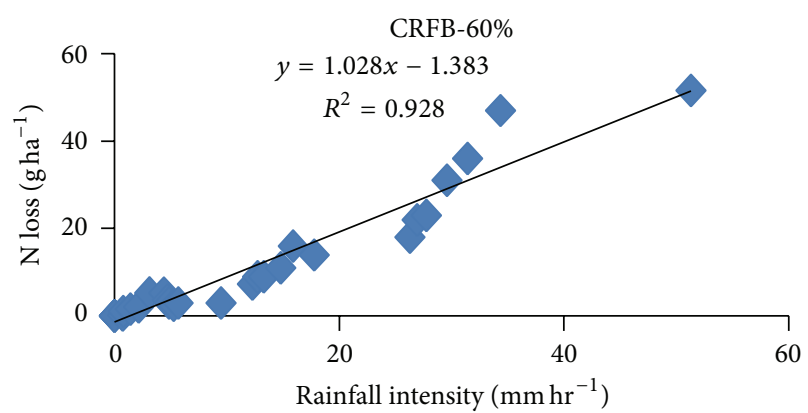

(c)

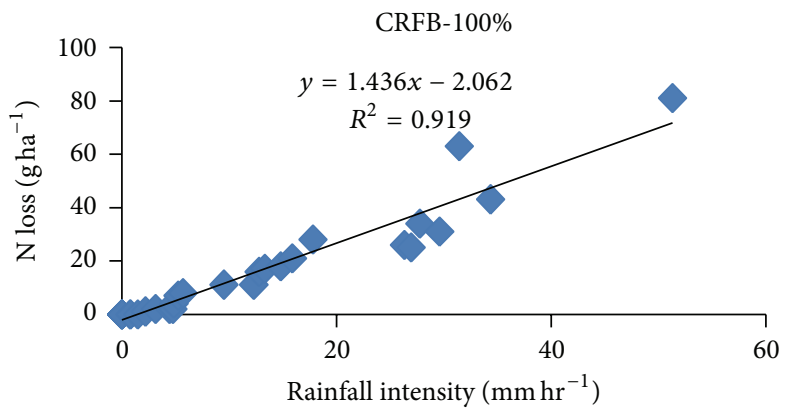

(e)

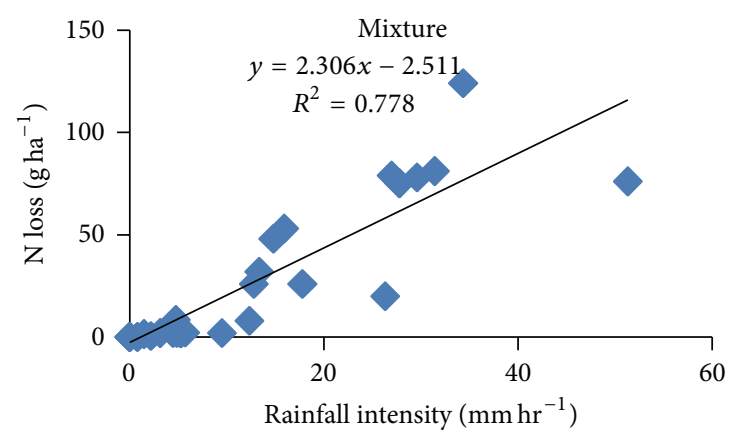

(b)

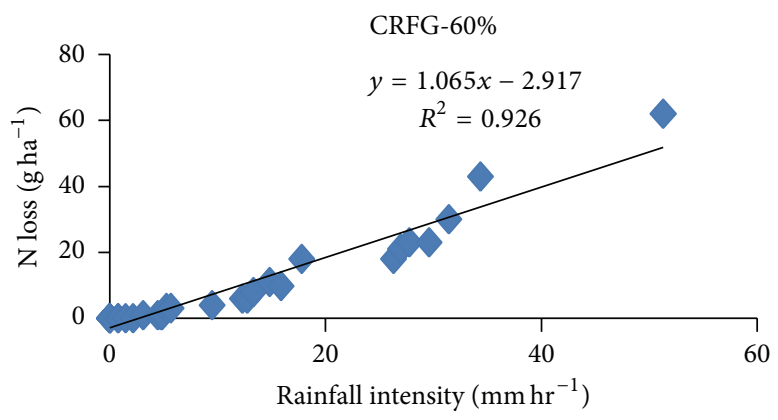

(d)

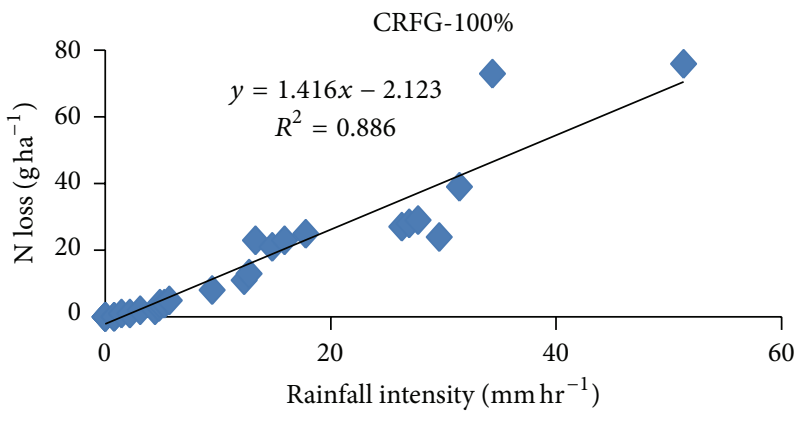

(f)

FIGURE 5: Relationship between rainfall intensity and nutrient $(\mathrm{N})$ loss for different fertilizer treatments following each rainfall event.

viability and environmental factors associated with nutrient loss, oil palm plantations may consider application of CRFs as an improved fertilizer management option. More research is needed to better elucidate mechanism of nutrient loss from oil palm ecosystems during specific storm events.

\section{Conflict of Interests}

The authors declare that there is no conflict of interests regarding the publication of this paper.

\section{Acknowledgments}

The authors wish to acknowledge Diversatech (M) Fertilizer Sdn. Bhd., Universiti Putra Malaysia, and Commonwealth Scholarship and Fellowship Plan (CSFP) through Ministry of Education Malaysia (MOE) for financial and technical support. Thanks are due to Madam Nor Asma Mohd Zaki for her help in the laboratory work.

\section{References}

[1] J. Shamshuddin and M. Anda, "Enhancing the productivity of ultisols and oxisols in Malaysia using basalt and/or compost," Pedologist, vol. 55, no. 3, pp. 382-391, 2012.

[2] J. P. Caliman, R. Carcasses, N. Perel et al., "Agri-environmental indicators for sustainable palm oil production," Palmas, vol. 28, pp. 434-445, 2007.

[3] K. J. Goh and R. Härdter, "General oil palm nutrition," in Oil Palm: Management for Large and Sustainable Yields, T. Fairhurst and R. Härdter, Eds., pp. 191-230, PPI/PPIC and IPI, Singapore, 2003.

[4] Food and Agriculture Organization of the United Nations (FAO), Fertilizer Use by Crop in Malaysia, FAO, Rome, Italy, 2004. 
[5] I. Comte, F. Colin, J. K. Whalen, O. Grünberger, and J.-P. Caliman, "Agricultural practices in oil palm plantations and their impact on hydrological changes, nutrient fluxes and water quality in indonesia. A review," Advances in Agronomy, vol. 116, pp. 71-124, 2012.

[6] S. Bricker, B. W. Longstaff, A. Dennison, K. Jones, C. Boicourt, and J. Woerner, "Effects of nutrient enrichment in the nations estuaries: a decade of change," in NOAA Coastal Ocean Program Decision Analysis, Series No. 26, National Centers for Coastal Ocean Science, Silver Spring, Md, USA, 2007.

[7] A. M. Freeman, E. C. Lamon III, and C. A. Stow, "Nutrient criteria for lakes, ponds, and reservoirs: a Bayesian TREED model approach," Ecological Modelling, vol. 220, no. 5, pp. 630639, 2009.

[8] E. E. Aziz and S. M. El-Asry, "Efficiency of slow release Urea fertilizer on herb yield and essential oil production of lemon balm (Melissa officinalis L.) plant," American-Eurasian Journal of Agricultural \& Environmental Sciences, vol. 5, no. 2, pp. 141147, 2009.

[9] R. Prasad, "Efficient fertilizer use: the key to food security and better environment," Journal of Tropical Agriculture, vol. 47, no. 1-2, pp. 1-17, 2009.

[10] P. P. Motavalli, K. W. Goyne, and R. P. Udawatta, "Environmental impacts of enhanced-efficiency nitrogen fertilizers," Crop Management, vol. 7, no. 1, 2008.

[11] K. A. Nelson, P. C. Scharf, L. G. Bundy, and P. Tracy, "Agricultural management of enhanced-efficiency fertilizers in the north-central United States," Crop Management, vol. 7, no. 1, 2008.

[12] A. Jarosiewicz and M. Tomaszewska, "Controlled-release NPK fertilizer encapsulated by polymeric membranes," Journal of Agricultural and Food Chemistry, vol. 51, no. 2, pp. 413-417, 2003.

[13] A. D. Blaylock, J. Kaufmann, and R. D. Dowbenko, "Nitrogen fertilizer technologies," in Proceedings of the Western Nutrient Management Conference, vol. 6, Salt Lake City, Utah, USA, 2005.

[14] International Fertilizer Industry Association (IFA), "Mineral Fertilizer Use and the Environment," 2000.

[15] T. Kenzo, R. Yoneda, Y. Matsumoto, M. A. Azani, and N. M. Majid, "Leaf photosynthetic and growth responses on four tropical tree species to different light conditions in degraded tropical secondary forest, Peninsular Malaysia," Japan Agricultural Research Quarterly, vol. 42, no. 4, pp. 299-306, 2008.

[16] G. W. Gee and J. W. Bauder, "Particle size analysis," in Methods of Soil Analysis. Part 1. Physican and Mineralogical Methods, A. Klute, Ed., pp. 383-411, ASA-SSSA, Madison, Wis, USA, 1986.

[17] C. B. S. Teh and J. Talib, Soil Physics Analysis, vol. 1, Universiti Putra Malaysia Press, Serdang, Malaysia, 2006.

[18] A. A. Ibitoye, Laboratory Manual on Basic Soil Analysis, Foladave, Akure, Nigeria, 2nd edition, 2006.

[19] J. B. Jones Jr., Laboratory Guide for Conducting Soil Tests and Plant Analysis, pp. 81-82, CRC Press, Boca Ranton, Fla, USA, 2001.

[20] A. Cottenie, Soil and Plant Testing as a Basis of Fertilizer Recommendations, FAO Soil Bulletin 38/2, FAO, Rome, Italy, 1980.

[21] K. H. Tan, Soil Sampling, Preparation and Analysis, Taylor and Francis/CRC Press, Boca Raton, Fla, USA, 2nd edition, 2005.

[22] G. W. Thomas, "Exchangeable cations," in Methods of Soil Analyes, A. L. Page, R. H. Miller, and D. R. Keeny, Eds., pp. 159165, American Society of Agronomy, Madison, Wis, USA, 1982.
[23] R. H. Bray and L. T. Kurtz, "Determination of total, organic and available forms of phosphorus in soils," Soil Science, vol. 59, pp. 39-45, 1945.

[24] S. Paramananthan, Soils of Malaysia: Their Characteristics and Identification, Academy of Sciences Malaysia, 2000.

[25] PORIM, Environmental Impacts of Oil Palm Plantations in Malaysia, Palm Oil Research Institute of Malaysia, 1994.

[26] A. E. Hartemink, "Soil erosion: perennial crop plantations," in Encyclopedia of Soil Science, Marcel Dekker, New York, NY, USA, 2006.

[27] R. H. V. Corley and P. B. Tinker, The Oil Palm, John Wiley \& Sons/CRC Press, Hoboken, NJ, USA, 4th edition, 2003.

[28] L. M. Maene, K. C. Tong, T. S. Ong, and A. M. Mokhtaruddin, "Surface wash under mature oil palm," in Proceedings of the Symposium on Water in Malaysian Agriculture, pp. 203-216, MSSS, Kuala Lumpur, Malaysia, 1979.

[29] K. J. Goh, C. B. Teo, P. S. Chew, and S. B. Chiu, "Fertilizer management in oil palm: agronomic principles and field practices," in Fertilizer Management for Oil Palm Plantations, vol. 44, pp. 20-21, ISP North-east Branch, Sandakan, Malaysia, 1999.

[30] M. Banabas, M. A. Turner, D. R. Scotter, and P. N. Nelson, "Losses of nitrogen fertiliser under oil palm in Papua New Guinea: 1. Water balance, and nitrogen in soil solution and runoff," Australian Journal of Soil Research, vol. 46, no. 4, pp. 332-339, 2008.

[31] K. J. Goh, R. Härdter, and T. Fairhurst, "Fertilizing for Maximum return," in Oil Palm: Management for Large and Sustainable Yields, T. Fairhurst and R. Härdter, Eds., pp. 279-306, PPI/PPIC and IPI, Singapore, 2003.

[32] K. K. Kee and P. S. Chew, "A13: Nutrient Losses through Surface Runoff and Erosion- Implications for Improved Fertilizer Efficiency in mature Oil Palm," Applied Agricultural Research Sdn. Bhd., Locked Bag no. 212, 1996.

[33] C. B. Wallace, M. G. Burton, S. G. Hefner, and T. A. DeWitt, "Effect of preceding rainfall on sediment, nutrients, and bacteria in runoff from biosolids and mineral fertilizer applied to a hayfield in a mountainous region," Agricultural Water Management, vol. 130, pp. 113-118, 2013.

[34] F. M. Ziadat and A. Y. Taimeh, "Effect of rainfall intensity, slope, land use and antecedent soil moisture on soil erosion in an arid environment," Land Degradation \& Development, vol. 24, no. 6, pp. 582-590, 2013.

[35] J. F. Martínez-Murillo, E. Nadal-Romero, D. Regüés, A. Cerdà, and J. Poesen, "Soil erosion and hydrology of the western Mediterranean badlands throughout rainfall simulation experiments: a review," Catena, vol. 106, pp. 101-112, 2013.

[36] J. S. Kim, S. Y. Oh, and K. Y. Oh, "Nutrient runoff from a Korean rice paddy watershed during multiple storm events in the growing season," Journal of Hydrology, vol. 327, no. 1-2, pp. 128-139, 2006.

[37] S. I. Ahmed, R. P. Rudra, B. Gharabaghi, K. Mackenzie, and W. T. Dickinson, "Within-storm rainfall distribution effect on soil erosion rate," ISRN Soil Science, vol. 2012, Article ID 310927, 7 pages, 2012.

[38] P. J. A. Kleinman, M. S. Srinivasan, C. J. Dell, J. P. Schmidt, A. N. Sharpley, and R. B. Bryant, "Role of rainfall intensity and hydrology in nutrient transport via surface runoff," Journal of Environmental Quality, vol. 35, no. 4, pp. 1248-1259, 2006.

[39] T. Fu, J. P. Ni, C. F. Wei, and D. T. Xie, "Research on nutrient loss from terra gialla soil in Three Gorges Region under different rainfall intensity," Journal of Soil and Water Conservation, vol. 16, no. 2, pp. 33-35, 83, 2002. 
[40] X. Chen, S. Q. Jiang, K. Z. Zhang, and Z. P. Bian, "Law of phosphorus loss and its affecting factors in red soil slope land," Journal of Soil Erosion and Soil and Water Conservation, vol. 5, no. 3, pp. 38-41, 1999.

[41] K. Jin, W. M. Cornelis, D. Gabriels et al., "Residue cover and rainfall intensity effects on runoff soil organic carbon losses," Catena, vol. 78, no. 1, pp. 81-86, 2009.

[42] J. P. Caliman, B. Dubos, B. Tailliez, P. Robin, X. Bonneau, and I. de Barros, "Oil palm mineral nutrition management: current situation and prospects," in Proceedings of the 14th International Oil Palm Conference, p. 33, Cartagena de Indias, Columbia, September 2003.

[43] Z. Fan, J. A. Moore, and D. L. Wenny, "Growth and nutrition of container-grown ponderosa pine seedlings with controlledrelease fertilizer incorporated in the root plug," Annals of Forest Science, vol. 61, no. 2, pp. 117-124, 2004. 


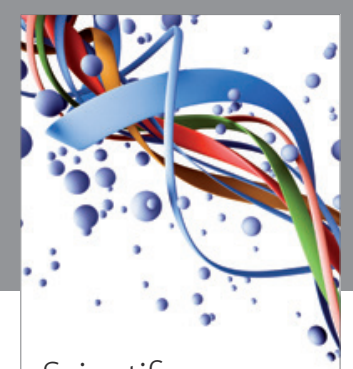

Scientifica
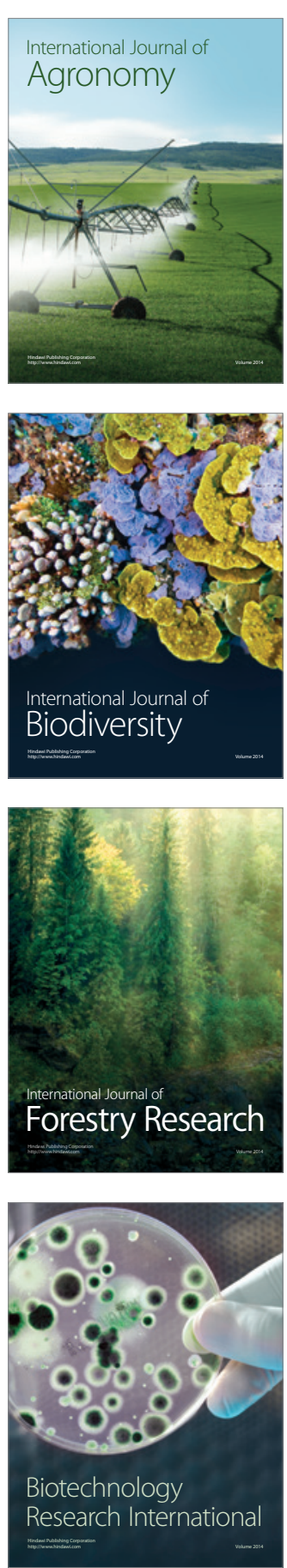
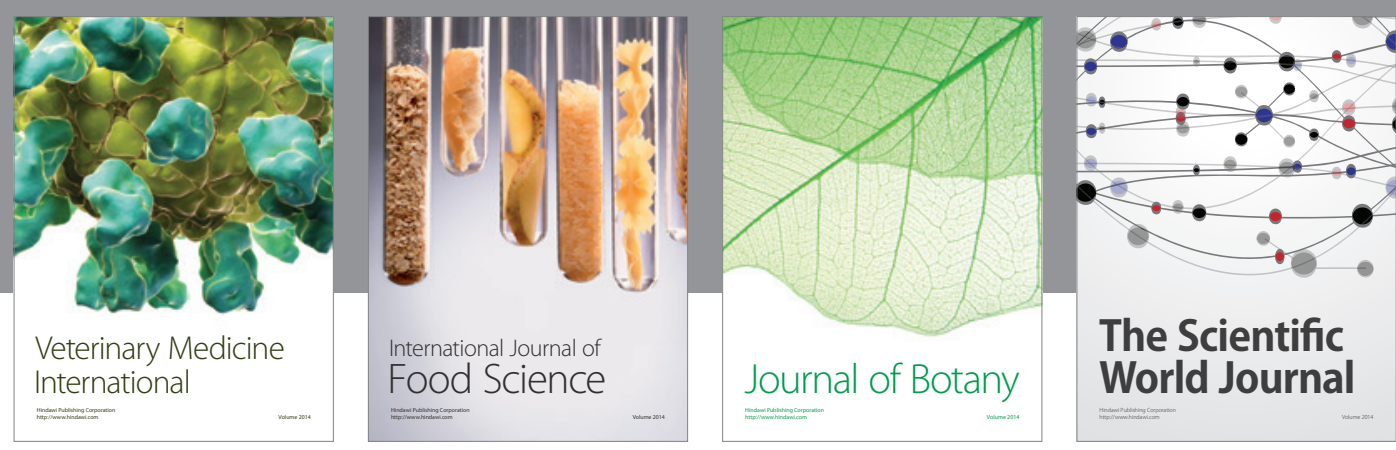

The Scientific World Journal
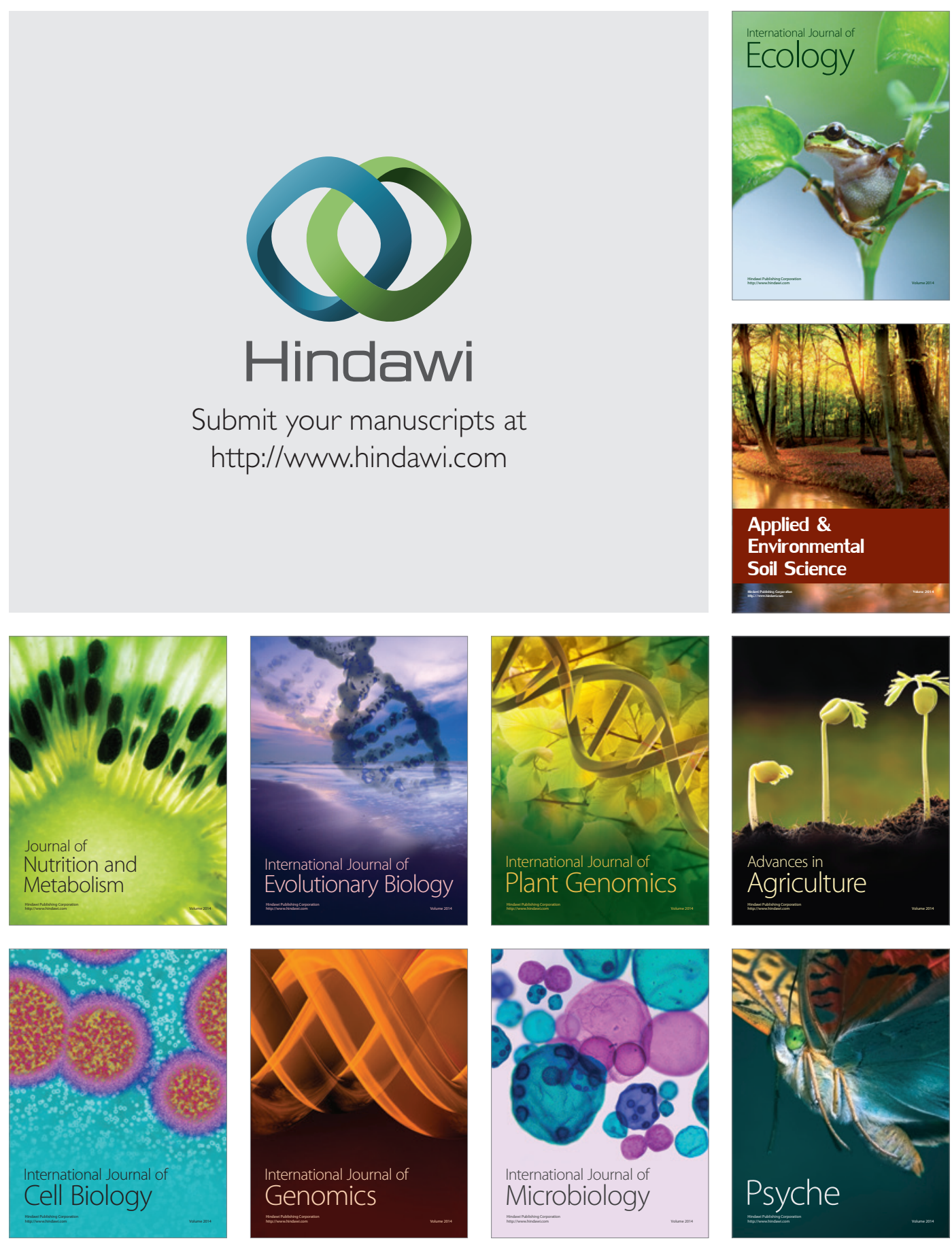